\title{
Quality of life of caregivers for patients of cerebrovascular accidents: association of (socio-demographic) characteristics and burden*
}

\author{
Qualidade de vida de cuidadores de indivíduos com acidente vascular \\ encefálico: associação com características e sobrecarga \\ Cualidad de vida de cuidadores de individuos con accidente vascular \\ encefálico: asociación con características y sobrecarga
}

Tatiana Ferreira da Costa ${ }^{1}$, Kátia Nêyla de Freitas Macêdo Costa ${ }^{2}$, Maria das Graças Melo Fernandes ${ }^{3}$, Kaisy Pereira Martins ${ }^{4}$, Silmery da Silva Brito ${ }^{5}$

\footnotetext{
* Extracted from the dissertation "Qualidade de vida relacionada à saúde de cuidadores familiares de indivíduos com sequela de acidente vascular encefálico," Post-Graduate program in Nursing, Universidade Federal da Paraíba, 2014.

${ }^{1}$ Doctorate, Post-Graduate program in Nursing, Universidade Federal da Paraíba, João Pessoa, PB, Brasil.

${ }^{2}$ Doctorate Professor, Department of clinical Nursing and Post-Graduate program in Nursing, Universidade Federal da Paraíba, João Pessoa, PB, Brasil.

${ }^{3}$ Doctorate Professor, Universidade Federal da Paraíba, João Pessoa, PB, Brasil.

${ }^{4}$ Master's, Post-Graduate program in Nursing, Universidade Federal da Paraíba, João Pessoa, PB, Brasil.

${ }^{5}$ Master's in Nursing, Universidade Federal da Paraíba, João Pessoa, PB, Brasil.
}

\begin{abstract}
Objective: Investigating the association between quality of life with socio-demographic characteristics and the burden of caregivers for individuals with cerebrovascular accident sequelae. Method: A descriptive, cross-sectional study with a sample composed of 136 caregivers. For data collection, a semi-structured questionnaire, the Barthel, Burden Interview and Short-Form-36 scales were used. Correlation analysis, t-Student test and F-test were used for the analysis in order to compare averages. Results: Significant averages in quality of life were demonstrated in association with female caregivers and those over 60 years in the field 'functional capacity', and in the domains of 'mental health' and 'vitality' for those with higher income. Regarding burden association, the highlighted areas were 'functional capacity,' 'physical aspects,' 'emotional aspects' and 'pain.' Conclusion: The creation of public policies and social support to effectively reduce the burden on caregivers is a necessity.
\end{abstract}

\section{DESCRIPTORS}

Stroke; Caregivers; Family; Quality of Life. 


\section{INTRODUCTION}

Cerebrovascular accident (CVA) is a well-documented and frequent neurological syndrome in adults and elderly, which constitutes a major cause of morbidity and mortality worldwide ${ }^{(1)}$. It can be defined as a rapidly developing syndrome of clinical disorder of brain functions, which results in a change of brain blood circulation possibly leading to transient or permanent neurological damage ${ }^{(2)}$. It can vary depending on the injury size and area of the brain artery that is affected, poor perfusion or collateral blood flow $^{(3)}$.

As a result of demographic epidemiological transition, CVA has become the second leading cause of death worldwide. Among all Latin America countries, Brazil has the highest mortality rates ${ }^{(4)}$. Equally troubling is the high rates of morbidity and disability, which generate considerable costs for the healthcare system, for the individual and their family members ${ }^{(5)}$.

When released from the hospital, the patient often returns home with physical, cognitive and behavioral consequences that commonly compromise their functional capacity, independence and autonomy ${ }^{(1)}$, making them dependent on others ${ }^{(6)}$. In most situations, only one member - the primary caregiver or informal caregiver - takes on the responsibility of care. They emerge as an important part of the actions through which they can maintain the autonomy, integration and participation of the affected individual in family relationships and society ${ }^{(1)}$.

However, it should be noted that the experience of caring for a dependent person has been described by family caregivers as an exhaustive and stressful task, which is related to the obstacles faced by families in caring for and coping with the impact of the illness upon disability and/or total dependence, with a change from a previous reciprocal relationship to a relationship of dependence ${ }^{(7)}$.

According to research, tension experienced by caregivers increases the risk of cardiovascular diseases and their risk of mortality to $23 \%$ and $63 \%$, respectively, when compared to non-caregivers ${ }^{(8)}$. These negative impacts on a caregiver's well-being may result in a disruption of the care and the stroke survivor's institutionalization, which imposes a substantial cost on health systems ${ }^{(9)}$. However, in the Brazilian context the caregiver figure has been devalued at both the governmental level (due to lack of infrastructure and strategies to systematically intervene in the context of the dependent) as well at the non-governmental level, including their families and health professionals. Therefore, caregivers are challenged by numerous demands and have restrictions regarding their own life, which contributes to the onset of burden.

This phenomenon has been measured in several ways, primarily through scales that assess problems arising from healthcare processes ${ }^{(10)}$, such as time available for care, financial, psychological, physical and social conditions, task management, and distribution of roles, among others ${ }^{(11)}$. If there is imbalance in any one of these areas and therefore the caregiver is exposed to burden, it can significantly affect their health, well-being and quality of life ${ }^{(12)}$. In Brazil, only a few scales have been constructed or culturally adapted to assess the burden of caregivers, with one of them being the Zarit Burden Intervierw ${ }^{(11)}$.

In a study to evaluate the quality of life of individuals affected by stroke and their caregivers using the WOQoLBref instrument, poorer quality of life in all areas was observed by the instrument when compared with a reference group $^{(13)}$. For this reason, qualified and multidisciplinary care for patients with stroke disabilities is necessary, and especially for the families of patients when the primary caregiver is in a burden situation, to make appropriate interventions that reduce the burden and improve the quality of life of this population, and thus the care provided to the dependent patient.

A meta-analysis intervention for caregivers of patients with stroke sequelae showed improvement in quality of life, levels of depression, stress, and in the sense of competence and problem-solving. Furthermore, interventions such as careful training of caregivers and psychoeducational skills ${ }^{(14)}$ reduced the health resource use of patients.

In recent years, the quality of life of family caregivers has been the subject of several studies(1,2). But there are still few studies that specifically address the caregivers of individuals that suffer from stroke disability, and especially about its relationship with socio-demographic characteristics and burden. The quality of life related to health has been increasingly studied in recent decades, and has become fundamental in relation to the context of health status, or variation of the impact that the disease causes in one's life, evident by themselves ${ }^{(15)}$. Therefore, it is an effective tool in the evaluation of changes concerning the caregiver's health, particularly in the burden situation.

Considering the points raised herein, the guiding question of this study was: What is the relationship between quality of life related to health with sociodemographic characteristics and the burden of caregivers to individuals with stroke sequelae?

Given the above, the objective of this research was to investigate the association between quality of life related to health with sociodemographic characteristics and the burden of caregivers of individuals with stroke sequelae.

\section{METHOD}

This is a descriptive, cross-sectional study with a quantitative approach, performed in the city of João Pessoa $\mathrm{PB}$, with the participation of caregivers to individuals with stroke sequelae, registered in Family Health Units (FHU) of that municipality which consists of five health districts and $181 \mathrm{FHU}$, divided as follows: district I having $45 \mathrm{FHU}$; district II having 36; the district III having 55; district IV having 26; and district $\mathrm{V}$ having 19 FHU.

The sample size calculation was based on an error margin of $5 \%$ (error $=0.05$ ) with a reliability degree of $95 \%$ $\left(\alpha=0.05\right.$ providing $\left.z_{0.05 / 2}=1.96\right)$, considering true proportion as 50\% ( $\mathrm{p}=0.50)$. Sample size was calculated based on the total of patients affected by stroke registered at the Family Heath Unit (ESF - in Portuguese). Therefore, according to the data of the five health districts in 2012 (the year before the research), there were 204 patients affected by stroke reg- 
istered at the ESF. The result of the sample size calculation revealed at least 134 caregivers of individuals affected by stroke. Interviews were conducted with 136 subjects.

Next, a random sampling of the FHU's from each district was conducted and a survey of the number of individuals affected by stroke registered in the ESF was made through the registration information of the monitored families. The adopted inclusion criteria were: age of 18 years or higher; having at least two activities of daily living (ADL) compromised according to the Barthel scale evaluation already validated in Brazil ${ }^{(16)}$; and having a family caregiver. Inclusion criteria for caregivers were an age of 18 years or higher and being the primary caregiver.

The Barthel scale measures the severity of disability in an individual. The version used evaluated the functional independence by measuring the ability of the individual to develop activities of daily living (ADL), based on information provided by their caregivers. This instrument comprises ten items that assess: control of bladder and bowel sphincter; personal hygiene; independence in the bathroom; independence for feeding; independence in transferring seats, walking, ability to dress and bathe, and climbing up stairs. In each item, the patient is assigned a score of $0,1,2$ or 3 , and in the end, the scores are added up to classify the patient as an independent or severely, moderately or mildly dependent ${ }^{(17)}$.

Data collection was conducted through household interviews with caregivers, from April to June 2013. Semistructured questionnaires were used with questions regarding sociodemographic characteristics of individuals with stroke sequelae (age, sex, marital status, education, employment status, personal income) and caregivers (age, sex, marital status, education, employment status, personal income, type of income and relationship to the patient).

To evaluate and rank the burden among caregivers, the Zarit Burden Interview scale was used, adapted and validated in $\mathrm{Brazil}^{(18)}$. This instrument consists of 22 questions. Each investigated item is scored and follows the scores of: never (0), rarely (1), sometimes (2) often (3), always (4). In the last question, the scores were: not at all (0), a little (1), moderate (2), very (3) extremely (4). The total score ranges from 0 to 88 , and the higher the score, the greater the perception of burden. The classification is based on the following scores: intense burden (scores between 61 to 88), moderate to severe burden (scores between 41 to 60 ), moderate to light burden (scores between 21 to 40) and no burden (scores lower than 21).

In evaluating the quality of life related to health, we used the Short-Form-36 questionnaire, which features eight domains: functional capacity, physical aspects, emotional aspects, mental health, social functioning, vitality, pain and general health perception. The score is from 0 to 100 , with higher values indicating better quality of life ${ }^{(18)}$.

For statistical analysis, the SPSS software (Statistical Package for Social Science) version 18.0 was used. In order to achieve the proposed objectives, it was necessary to apply two statistical approaches: Correlation analysis, and Student's t-test and F-test in order to compare the demographic data averages of caregivers.
All ethical procedures have been complied with all legal and ethical issues involving human subjects, recommended by Resolution 466/12 of the Conselho Nacional de Saúde ${ }^{(19)}$. The project was submitted to the Ethics Committee of the Center of Health Sciences, Universidade Federal da Paraíba, and approved under Protocol No. 0279/13 and CAAE: 13778313.3.0000.5188. The principle of autonomy and privacy was respected, especially with regard to signing of the Informed Consent form, an indispensable tool in conducting research with human subjects.

\section{RESULTS}

Regarding the sociodemographic characteristics of individuals with stroke sequelae, a prevalence of females (51.40\%), an average age of 70.43 years, married (48.53\%), with schooling between one and four years of study (27.94\%), retired (80.88\%), with personal income between two and three minimum wages $(61.76 \%)$ was found. As for functional incapacity, the study showed that 35 (25.74\%) patients had mild dependence, 35 (25.74\%) very serious, 28 (20.59\%) were severely dependent, and 27 (19.85\%) had moderate dependence.

Regarding the characteristics of caregivers, the research found that most were female (84.50\%), children (51.47\%), had an average age of 34 to 47 years old, married (57.35\%), and schooling between five and nine years (51.47\%). As for the employment status, there was a predominance of unemployed caregivers (45.59\%) with personal income between one and three minimum wages (58.09\%).

\section{Association BetWeen the SF-36 WITH \\ SOCIODEMOGRAPHIC CHARACTERISTICS OF THE FAMILY \\ CAREGIVERS OF INDIVIDUALS WITH STROKE SEQUELAE}

Regarding the association of the domains of the HRQoL scale and sociodemographic characteristics of caregivers, there was only a significant difference between the average scores of men and women for the domain of 'functional capacity of the HRQoL scale,' in which the female caregivers (71.13) had a worse quality of life compared to the men (83.81).

Table 1 - Comparison of the average scores for the domains of HRQoL scale, according to the gender of caregivers - João Pessoa, PB, 2013.

\begin{tabular}{lcc}
\hline HRQoL Domains & Female $(\mathbf{n}=\mathbf{1 1 5})$ & Male $(\mathbf{n}=\mathbf{2 1})$ \\
\hline Physical Aspects & 53.70 & 65.00 \\
Emotional Aspects & 59.42 & 66.67 \\
Pain & 41.81 & 31.22 \\
Functional Capacity & $71.13^{*}$ & $83.81^{*}$ \\
Social Aspects & 52.87 & 60.95 \\
Mental Heath & 53.73 & 53.06 \\
Vitality & 65.51 & 64.76 \\
State of General Heath & 54.58 & 52.01 \\
\hline
\end{tabular}

(*) Statistically significant average scores.

In terms of age, it was observed that caregivers older than 60 years had a statistically lower score in the field 
'functional capacity' (63.70), compared with lower age. Those with less than 40 years had lower scores in the field 'Pain' (30.48) compared to older.

For marital status there was a significant difference between the average scores of single/divorced/widowed to married caregivers in the fields of 'emotional aspects' and 'mental health.' In other areas, the average scores observed between the two categories are equivalent.

As to the association of the HRQoL scale domains and the level of education, significant differences among the average scores of the four grade levels measured for any of the eight domains were not found. With regard to personal income (Table 4), those with higher incomes had higher scores in the areas 'mental health' (64.63) and 'vitality' (76.51).

Table 2 - Comparison of average scores obtained for the domains of HRQoL according to the age of caregivers - João Pessoa, PB, 2013.

\begin{tabular}{lccc}
\hline HRQoL Domains & $\begin{array}{c}<\mathbf{4 0} \text { years } \\
(\mathbf{n}=\mathbf{3 9})\end{array}$ & $\begin{array}{c}\mathbf{4 0}-\mathbf{6 0} \text { years } \\
(\mathbf{n = 7 0 )}\end{array}$ & $\begin{array}{c}>\mathbf{6 0} \text { years } \\
(\mathbf{n}=\mathbf{2 7})\end{array}$ \\
\hline Physical Aspects & 64.74 & 48.55 & 59.26 \\
Emotional Aspects & 64.96 & 55.71 & 66.67 \\
Pain & $30.48^{*}$ & $44.61^{*}$ & $42.80^{*}$ \\
Functional Capacity & $84.62^{*}$ & $70.29^{*}$ & $63.70^{*}$ \\
Social Aspects & 57.95 & 52.29 & 53.33 \\
Mental Heath & 54.03 & 55.20 & 48.94 \\
Vitality & 65.81 & 65.71 & 63.95 \\
State of General Heath & 53.85 & 57.14 & 47.01 \\
\hline
\end{tabular}

$\left({ }^{*}\right)$ Statistically significant average scores.

Table 3 - Comparison of average scores for domains of the HRQoL scale, according to the marital status of the caregivers João Pessoa, PB, 2013.

\begin{tabular}{lcc}
\hline HRQoL Domains & $\begin{array}{c}\text { Single/Divorced/ } \\
\text { Widowed (n=58) }\end{array}$ & $\begin{array}{c}\text { Married } \\
(\mathbf{n = 7 8 )}\end{array}$ \\
\hline Physical Aspects & 52.16 & 57.79 \\
Emotional Aspects & $53.45^{*}$ & $65.81^{*}$ \\
Pain & 39.46 & 40.69 \\
Functional Capacity & 74.66 & 71.92 \\
Social Aspects & 50.34 & 56.92 \\
Mental Heath & $48.52^{*}$ & $57.42^{*}$ \\
Vitality & 64.71 & 65.90 \\
State of General Heath & 53.58 & 54.64 \\
\hline
\end{tabular}

(*) Statistically significant average scores.

\section{Association BetweEn the SF-36 With THE TOTAL SCORES OF THE ZARIT SCALE OF FAMILY CAREGIVERS OF INDIVIDUALS WITH STROKE SEQUELAE/DISABILITIES}

In the Zarit Burden Interview application, burden prevalence among caregivers was equivalent to $77.20 \%$. Considering the burden levels, $79(58.00 \%)$ had moderate to mild burden, 31 (22.80\%) no burden, and 26 (19.00\%) moderate to severe burden.

As described in Table 5, there was statistically significant correlation in the areas of 'physical aspects,' 'emotional aspects, 'pain' and 'functional capacity' of the SF-36 with the total scores of the Zarit scale.
Table 4 - Comparison of the average scores for the domains of the HRQoL scale, according to the personal income of caregivers - João Pessoa, PB, 2013.

\begin{tabular}{|c|c|c|c|c|}
\hline HRQoL Domains & $\begin{array}{l}\text { Less } \\
\text { than } 1 \\
\text { M.W. } \\
(\mathbf{n}=20)\end{array}$ & $\begin{array}{c}\text { Between } \\
1-3 \\
M . W . \\
(n=79)\end{array}$ & $\begin{array}{c}\text { Between } \\
3-5 \\
\text { M.W. } \\
(n=15)\end{array}$ & $\begin{array}{l}\text { More } \\
\text { than } 5 \\
\text { M.W. } \\
(n=21)\end{array}$ \\
\hline Physical Aspects & 50.00 & 61.39 & 38.33 & 50.00 \\
\hline Emotional Aspects & 55.00 & 63.71 & 33.33 & 71.43 \\
\hline Pain & 47.22 & 37.83 & 47.62 & 38.10 \\
\hline Functional Capacity & 72.00 & 75.63 & 56.67 & 75.24 \\
\hline Social Aspects & 58.00 & 54.43 & 46.67 & 54.29 \\
\hline Mental Heath & $54.29 *$ & $52.35^{*}$ & $43.33^{*}$ & $64.63 *$ \\
\hline Vitality & $63.67^{*}$ & $64.64^{*}$ & $56.89^{*}$ & $76.51^{*}$ \\
\hline State of General Heath & 58.46 & 55.79 & 51.79 & 46.52 \\
\hline
\end{tabular}

Table 5 - Correlation analysis (Spearman coef.) of the scores obtained for the SF-36 with the total scores of the Zarit scale of caregivers - João Pessoa, PB, 2013.

\begin{tabular}{lcc}
\hline \multirow{2}{*}{ HRQoL Domains } & \multicolumn{2}{c}{ Zarit } \\
\cline { 2 - 3 } & $\mathbf{R}$ & Valor-p \\
\hline Physical Aspects & -0.363 & $0.0000^{*}$ \\
Emotional Aspects & -0.361 & $0.0000^{*}$ \\
Pain & 0.373 & $0.0000^{*}$ \\
Functional Capacity & -0.310 & $0.0002^{*}$ \\
Social Aspects & -0.047 & 0.5880 \\
Mental Heath & -0.164 & 0.0563 \\
Vitality & 0.056 & 0.5174 \\
State of General Heath & 0.042 & 0.6257 \\
\hline * Significant correlation at 5\% & &
\end{tabular}

* Significant correlation at 5\%

\section{DISCUSSION}

The SF-36 assesses the quality of life related to health and has been an instrument widely used to measure the impact of health changes in the quality of life of caregivers for individuals with stroke sequelae in Brazil and around the world ${ }^{(20-21)}$.

The present study checked the correlation between the quality of life related to health with sociodemographic characteristics and caregiver burden. The scores of the domain 'functional capacity'were higher in male and younger caregivers, but the latter had lower scores in the domain of 'pain.'The average domain scores of 'emotional aspects' and 'mental health' were higher in married caregivers compared to others, and those with lower income had lower scores for 'vitality' and 'mental health.' However, this study showed no significant correlation between the average scores of the four grade levels measured for any of the eight domains.

In relation between quality of life and the burden on family caregivers, a statistically significant association was observed between domain scores of 'physical aspects,'emotional aspects,' 'pain' and 'functional capacity' with the total Zarit scale scores.

The domain 'functional capacity' is the presence and the extension of limitation due to physical capacity. In this study, older female caregivers were observed to be more affected. Other research has also shown similar results ${ }^{(20-22)}$. 
Caregivers with more advanced age are more prone to the negative impact of care, due to increased vulnerability to illness from senescence ${ }^{(10-23)}$, as well as the fact that it is women who usually accumulate various roles throughout life, both in society and in caring for the children, the spouse, and the household chores.

The reduction in the functional capacity of the caregiver is presented as an obstacle in the care provided, due to the need to be physically fit to perform the physical care of the dependent patient. Thus, this may affect both the rehabilitation and reintegration of patients into society as well as the health of the caregiver itself, which was demonstrated in this study by the correlation with the highest level of burden.

Some authors state that younger caregivers suffer the greatest impact of the activity of caring in their quality of life, because often they put their professional and social life aside to engage in this activity ${ }^{(24)}$. There are also those with higher burden due to the various activities that are imposed on them, such as jobs, the demands coming from the family and the care of dependent family, who have increased the load of stress and of physical and psychological strain. They had a lower score in the domain of 'pain,' showing a relation with higher levels of burden. A study ${ }^{(21)}$ also showed an impact of care among younger female family caregivers for the presence of signs of depression.

Domains of 'emotional aspects' and 'mental health' are related to well-being and emotional and psychological changes, triggering feelings of anxiety, distress and depression $^{(20)}$, which further increases the tension experienced with a negative impact on care provided ${ }^{(23)}$. In other studies, these areas were the most affected ${ }^{(13)}$. Married caregivers had higher scores in these areas compared to others. There was also a relationship between emotional aspects and burden.

The presence of a marriage partner of the patient can often be a factor that provides intense emotional strengthening for the caregiver, making them less lonely and receiving more support when there is a good relationship between the couple. However, in other cases it may be the opposite; the marriage can be a stressor because there is more of a role that the spouse has to play ${ }^{(23)}$. The psychological well-being can promote healthy and conscious behaviors, giving balance so that the patient can understand much more about the manifestations and impact of their disability. This can be done by employing individual strategies developed to circumvent the limitations and provide more autonomy to the patient ${ }^{(13)}$.

In this research, caregivers with lower income showed lower scores for 'mental health' and 'vitality.'The latter consists of four items that consider the level of energy and fatigue. The loss of one's independence leads to the need to adapt, as to the purchase of materials for the development of the new routine and architectural adaptations in the physical structure of the home ${ }^{(2)}$. However, when the provision of care takes place in conditions of scarcity, and the situation is seen by the caregiver as a duty and they have no alternative option. Therefore, this activity causes stress and feeling of anxiety among caregivers seeking to provide the best care for the family dependent ${ }^{(10-25)}$.
Decreased energy and increased fatigue in daily caregiver activities impact on the quality of care provided. The individuals affected by stroke have limitations and / or compromises on all of the functionality and performance of activities, the reason for needing the care to provide to the patient more autonomy and independence ${ }^{(13)}$.

With regard to education, some authors mention that low literacy levels may negatively influence the emotional aspects of caregivers. A study by Ferreira ${ }^{(26)}$ showed that the caregivers with higher levels of education had higher scores in the domain 'general health.' However, in this study there was no correlation with any of the domains.

Studies have shown high rates of burden placed on family caregivers of patients with stroke sequelae, mainly related to stress, isolation, and poorer quality of life ${ }^{(2,12,20)}$. Similarly, this research has also shown a negative correlation with the quality of life related to health in the domains of 'functional capacity,' 'physical aspects' 'pain' and 'emotional aspects.'

Some authors point out that the burden of care can be generated by the individual characteristics of caregivers themselves, as well as their health and economic status ${ }^{(27)}$. In addition, it is noted that the lack of support from other family members and health staff guidelines for dealing with specific aspects of the patient's condition or its degree of dependence makes the caregiver use ineffective strategies, which cause emotional changes and further increase the tension ${ }^{(20)}$.

Caregivers feel guilty, both from losing control emotionally while facing a care situation and by feeling responsible in any way for the disability state of their family member ${ }^{(28)}$. So, now there are difficulties to set limits on the care they provide and they end up performing it to exhaustion ${ }^{(29)}$.

In this context, the burden, feelings of fear, pain, loss and lack of perceived control, and guilt are often present in the care process, and they promote a deficiency in self-care and generate a negligence cycle on the caregiver's own health. In this cycle, the lack of health promotion behaviors associated with the adverse effects of prolonged tension from their role as caregiver deteriorates their own health, causing aging, for example, which leads to dependency in their old age, when they will need a caregiver. This is how the cycle is perpetuated ${ }^{(24)}$.

A survey conducted in Colombia with family caregivers aiming to assess the most frequent needs of caregivers revealed that the aspects related to physical, emotional and socioeconomic health were the most correlated with depression and burden ${ }^{(30)}$.

Another study of family caregivers living in Canada and in England showed that depression was correlated to poorer quality of life, especially with physical aspects, and were also more prevalent in caregivers of patients with more symptoms of depression and cognitive impairment ${ }^{(21)}$. In this context, research conducted in the United States can also be mentioned; its objective was to evaluate an intervention program through a telephoning program designed to train and guide family caregivers of patients with stroke sequelae after four, eight, and twelve weeks ${ }^{(31)}$. As a result, family caregivers improved the quality of life, symptoms of depression, general health, optimism and difficulties in tasks performed. Upon further investigation, we observed 
the satisfaction of caregivers with the telephoning program and evidence of validity in relation to the accuracy, feasibility, acceptability and relevance ${ }^{(32)}$.

It is clear then that the task of caring alone does not lead to symptoms of depression, health problems or social isolation for the caregiver. Many caregivers need training, education, rest and care for their physical and mental health ${ }^{(20)}$. For this, they need the help of other family members for the relay of care, guidance and health training to deal with specific aspects of the patient's condition or its degree of dependence. Services and trained professionals to support caregivers in coping with their difficulties have been a very favorable means to strengthen them and lessen the burden of care ${ }^{(33)}$.

\section{CONCLUSION}

The results presented in this study showed the relationship between the association of quality of life and sociodemographic data of the caregiver. The study showed that the average of the domain 'functional capacity' was lower in female caregivers and those over 60 years. The domain of 'pain' showed lower score among caregivers under 40 years. The domains of 'emotional aspects' and 'mental health' had lower averages between single/divorced/widowed caregivers. The domain scores for 'mental health' and 'vitality' were higher in caregivers whose income was higher.

Even with regard to the factors that influence the quality of life of caregivers, this study found that the burden resulted in a poorer quality of life related to health in the domains of 'functional capacity,' 'physical aspects,' 'emotional aspects' and 'pain.'

The findings of this study allowed us to understand the different dimensions and characteristics in the context of quality of life related to health, characterizing it as a multifaceted and multidimensional phenomenon in respect to the study population, which enabled the targeting of specific interventions for these caregivers. Therefore, it is clear that in the setting of care structure, public policies and social support must be created and implemented to be effective in managing care, reducing burden and hence improving the quality of life.

In the context of nursing care, this research provides reflection on interventions to improve the quality of life of caregivers, advising on the care provided by family members, as the relay between the family members and the provision of care only for activities that the individual cannot perform, in order to promote maximum independence and autonomy to patients and reduce the burden on the caregiver.

In this sense, it is worth noting that nurses and other professionals must be prepared to assist, in a holistic manner, the problems and difficulties faced by the family, especially the primary caregiver. For this, it is suggested that support programs are created, social support and training for these professionals so that they can deal with the situation of dependence in the family sphere, and new research is conducted on the theme presented with a view to elucidate this problematic, yet little discussed or worked on area in caring for patients.

In this study, the limitations were related to the absence in intervention studies of literature in Brazil aimed at these caregivers. This requires the development of more research in this area and validation of specific scales to be applied to relatives of patients affected by stroke, which may bring more reliable data on this population.

\section{RESUMO}

Objetivo: Averiguar a associação entre a qualidade de vida com as características sociodemográficas e a sobrecarga de cuidadores de indivíduos com sequela de acidente vascular encefálico. Método: Pesquisa descritiva, transversal cuja amostra foi composta por 136 cuidadores. Para a coleta dos dados, aplicou-se um questionário semiestruturado e as escalas de Barthel, Burden Interview e Short-Form-36. Para a análise, foram aplicados o teste de correlação e o teste $t$ de Student e F para comparar as médias. Resultados: Demonstraram médias significativas na associação da qualidade de vida com os cuidadores do sexo feminino e maiores de 60 anos no domínio 'capacidade funcional', e os com maior renda, nos domínios 'saúde mental' e 'vitalidade'. Na associação com a sobrecarga, foram os domínios 'capacidade funcional', 'aspectos físicos', 'aspectos emocionais' e 'dor'. Conclusão: É preciso criar políticas públicas e suporte social que sejam efetivos para reduzir a sobrecarga dos cuidadores.

\section{DESCRITORES}

Acidente Vascular Cerebral; Cuidadores; Família; Qualidade de Vida.

\section{RESUMEN}

Objetivo: Verificar la asociación entre la calidad de vida con las características sociodemográficas y la sobrecarga de cuidadores de individuos con secuela de accidente vascular encefálico. Método: Investigación descriptiva, transversal, cuya muestra estuvo compuesta de 136 cuidadores. Para la recolección de los datos, se aplicó un cuestionario semiestructurado y las escalas de Barthel, Burden Interview y Short-Form-36. Para el análisis, se aplicaron la prueba de correlación y la prueba $t$ de Student y F para comparar los promedios. Resultados: Demostraron promedios significativos en la asociación de la calidad de vida con los cuidadores del sexo femenino y mayores que 60 años en el dominio 'capacidad funcional', y los con mayor renta, en los dominios 'salud mental' y 'vitalidad'. En la asociación con la sobrecarga, fueron los dominios 'capacidad funcional', 'aspectos físicos', 'aspectos emocionales' y 'dolor'. Conclusión: Es preciso crear políticas públicas y soporte social que sean efectivos para reducir la sobrecarga de los cuidadores.

\section{DESCRIPTORES}

Accidente Cerebrovascular; Cuidadores; Familia; Calidad de Vida. 


\section{REFERENCES}

1. Pereira RA, Santos EB, Fhon JRS, Marques S, Rodrigues RAP. Burden on caregivers of elderly victims of cerebrovascular accident. Rev Esc Enferm USP [Internet]. 2013 [cited 2014 Jan 13];47(1):185-92. Available from: http://www.scielo.br/pdf/reeusp/v47n1/en_a23v47n1.pdf

2. Oliveira BC, Garanhani ML, Garanhani MR. Caregivers of people with stroke: needs, feelings and guidelines provided. Acta Paul Enferm. $2011 ; 24(1): 43-9$

3. Delboni MCC, Malengo PCM, Schmidt EPR. Relação entre os aspectos das alterações funcionais e seu impacto na qualidade de vida das pessoas com sequelas de Acidente Vascular Encefálico (AVE). Mundo da Saúde. 2010;34(2):165-75.

4. Garritano CR, Luz PM, Lúcia M, Pires E, Teresa M, Barbosa S, et. al. Analysis of the mortality trend due to cerebrovascular accident in Brazil in the XXI century. Arq Bras Cardiol. 2012;98(6):519-27.

5. Saliba VA, Magalhães LC, Faria CDCM, Laurentino GEC, Cassiano JG, Teixeira-Salmela LF. Adaptação transcultural e análise das propriedades psicométricas da versão brasileira do instrumento Motor Activity Log. Rev Panam Salud Pública. 2011;30(3):262-71.

6. Santos SAL, Tavares DMS, Barbosa MH. Fatores socioeconômicos, incapacidade funcional e número de doenças entre idosos. Rev Eletr Enferm [Internet]. 2010 [citado 2013 out. 27];12(4):692-7. Disponível em: http://www.fen.ufg.br/fen_revista/v12/n4/v12n4a14.htm

7. Vieira CPB, Fialho AVM, Freitas CHA, Jorge MSB. Práticas do cuidador informal do idoso no domicílio. Rev Bras Enferm. 2011;64(3):570-9.

8. Haley WE, Roth DL, Howard G, Safford MM. Caregiving strain and estimated risk for stroke and coronary heart disease among spouse caregivers: differential effects by race and sex. Stroke. 2010;41(2):331-6.

9. McLennon SM, Habermann B, Davis LL. Deciding to institutionalize: why do family members cease caregiving at home? J Neurosci Nurs. 2010;42(2):95-103.

10. Loureiro LSN, Fernandes MGM, Marques S, Nóbrega MML, Rodrigues RP. Burden in family caregivers of the elderly: prevalence and association with characteristics of the elderly and the caregivers. Rev Esc Enferm USP [Internet]. 2013 [cited 2014 Jan 20];47(5):1133-40. Available from: http://www.scielo.br/pdf/reeusp/v47n5/0080-6234-reeusp-47-05-1129.pdf

11. Oliveira ARS, Costa AGS, Sousa VEC, Araujo TL, Silva VM, Lopes MVO, et al. Escalas para avaliação da sobrecarga de cuidadores de pacientes com Acidente Vascular Encefálico. Rev Bras Enferm. 2012;65(5):839-43.

12. Morais HCC, Soares AMG, Oliveira ARS, Carvalho CML, Silva MJ, Araujo TL. Burden and modifications in life from the perspective of caregivers for patients after stroke. Rev Latino Am Enfermagem. 2012;20(5):944-53.

13. Lima ML, Santos JLF, Sawada NO, Lima LAP. Quality of life of individuals with stroke and their caregivers in a city of Triângulo Mineiro. Rev Bras Epidemiol. 2014;17(2):453-64.

14. Cheng H, Chair SY, Chau JPC. The effectiveness of psychosocial interventions for stroke family caregivers and stroke survivors: A systematic review and meta-analysis. Patient Educ Couns. 2014;95(1):30-44.

15. Cavalcante MCV, Lamy ZC, Lamy Filho F, França AKTC, Santos AM, Thomaz EBAF, Silva AAM, Salgado-Filho N. Fatores associados à qualidade de vida de adultos em hemodiálise em uma cidade do nordeste do Brasil. J Bras Nefrol 2013;35(2):79-86.

16. Minosso JSM, Amendola F, Alvarenga MRM, Oliveira MAC. Validation of the Barthel Index elderly patients attended in outpatient clinics in Brazil. Acta Paul Enferm. 2010;23(2):218-23.

17. Scazufca M. Versão brasileira da escala Burden: interview para avaliação de sobrecarga em cuidadores de indivíduos com doenças mentais. Rev Bras Psiquiatr. 2002;24(1):12-7.

18. Ciconelli RM, Ferraz MB, Santos W, Meinão I, Quaresma MR. Tradução para a língua portuguesa e validação do Questionário Genérico de Avaliação de Qualidade de Vida SF-36. Rev Bras Reumatol. 1999;39(3):143-50.

19. Brasil. Ministério da Saúde; Conselho Nacional de Saúde. Resolução n. 466, de 12 de dezembro de 2012. Dispõe sobre diretrizes e normas regulamentadoras de pesquisas envolvendo seres humanos [Internet]. Brasília; 2012 [citado 2014 maio 17]. Disponível em: http:// conselho.saude.gov.br/resolucoes/2012/Reso466.pdf

20. Amendola F, Oliveira MA, Alvarenga MRM. Qualidade de vida dos cuidadores de pacientes dependentes no Programa de Saúde da Família. Texto Contexto Enferm. 2008;17(2):266-72.

21. Cameron JI, Cheung AM, Streiner DL, Coyte PC, Stewart DE. Stroke survivor depressive symptoms are associated with family caregiver depression during the first 2 years poststroke. Stroke. 2011;42(2):302-6.

22. Ferreira CG, Alexandre TS, Lemos ND. Fatores associados à qualidade de vida de cuidadores de idosos em assistência domiciliária. Saúde Soc. 2011;20(2):398-409.

23. Fernandes MGM, Garcia TR. Determinantes da tensão do cuidador familiar de idosos dependentes. Rev Bras Enferm. 2009;62(1):57-63.

24. Fernandes MGM, Garcia TR. Estrutura conceitual da tensão do cuidador familiar de idosos dependentes. Rev Eletr Enferm [Internet]. 2009 [citado 2013 nov. 15];11(3):469-76. Disponível em: http://www.fen.ufg.br/fen_revista/v11/n3/pdf/v11n3a02.pdf

25. Gratão ACM, Talmelli LFS, Figueiredo LC, Rosset I, Freitas CP, Rodrigues RAP. Functional dependency of older individuals and caregiver burden. Rev Esc Enferm USP [Internet]. 2013 [cited 2014 Jan 28];47(1):137-44. Available from: http://www.scielo.br/pdf/reeusp/v47n1/ en_a17v47n1.pdf

26. Simonetti JP, Ferreira JC. Estratégias de coping desenvolvidas por cuidadores de idosos portadores de doença crônica. Rev Esc Enferm USP. 2008;42(1):19-25.

27. Lecovich E. Caregiving burden, community services, and quality of life of primary caregivers of frail elderly persons. J Appl Gerontol. 2008;27(3):309-30.

28. Fernandes MGM, Garcia TR. Tension attributes of the Family caregiver of frail older adults. Rev Esc Enferm USP [Internet]. 2009 [cited 2013 Nov 19];43(4):818-24. Available from: http://www.scielo.br/pdf/reeusp/v43n4/en_a12v43n4.pdf 
29. Freira IBA, Meneghel SN, Selli L. A construção do cuidado pela equipe de saúde e o cuidador em um programa de atenção domiciliar ao acamado em Porto Alegre (RS, Brasil). Ciênc Saúde Coletiva. 2013;16(1):301-10.

30. Arango-Lasprilla JC, Plaza SLO, Drew A, Romero JLP, Pizarro JAA, Francis K, Kreutzer J. Neurorehabilitation. Family needs and psychosocial functioning of caregivers of individuals with spinal cord injury from Colombia, South America. Neurorehabilitation. 2010;27(1):83-93.

31. Bakas T, Farran CJ, Austin JK, Given BA, Johnson EA, Williams LS. Stroke caregiver outcomes from the Telephone Assessment and SkillBuilding Kit (TASK). Top Stroke Rehabil. 2009;16(2):105-21.

32. Bakas T, Farran CJ, Austin JK, Given BA, Johnson EA, Williams LS. Content validity and satisfaction with a stroke caregiver intervention program. J Nurs Scholarsh. 2009;41(4):368-75.

33. Amendola F, Oliveira MAC, Alvarenga MRM. Influence of social support on the quality of life of family caregivers while caring for people with dependence. Rev Esc Enferm USP [Internet]. 2011 [cited 2013 Nov 27];45(4):884-9. Available from: http://www.scielo.br/pdf/reeusp/ v45n4/en_v45n4a13.pdf 